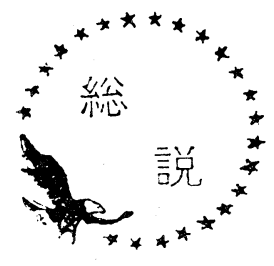

通常, $200^{\circ} \mathrm{C}$ 前後が使用限界で, それ以上の温度で 虹変質, 分解してしまう高分子物質が, 口ケットの数 千度といら高温に対する耐熱材料として, 金属やセラ ミックスに代つて進出してきている。このような耐熱 性が高分子物質のいかなる特性に起因するのか, これ を紹介するのが本稿の主題である。しかしその前に， ロケット全般にわたる高分子物質の利用分野をごく簡 単に概観しておくのも無意味ではないと思う。

\section{I . ロケットにおける高分子材料}

高分子物質が，高強度を必要としないパイプ，パネ ルなどの部分的構造 材とか, 主構造材の接着剤, 塗 料, パッキング，断熱材などに，また計器類の電気絶 縁や防震材にと副次的な意味で多様に用いられている ことは，何もロケットに限らず，目新しいことでもな いが,こうした材料の進歩に伴ない, ますます適材適 処の原則に従つて多方面に進出し, 高分子製ロケット 部品の数は数干種にのぼるといわれている11。副次的 とはいつても場合によつては致命的重要性をもつこと もあり，たとえば，Juno 初期打上げの失敗は, 誘導 計器の防震処理の不完全さによるものであつたと考え られている2)。

現在ロケットにおいてもつとも多量に高分子物質が 用いられているのは, 固体推進剤の分野である。固体 酸化剂を合成プラスチックに分散させて成型する混成 系推進剤がその主流であり,プラスチックは被酸化剂 であると同時に燃料結合材としての役割を果してい る。ポリウレタン, ポリブタジエン, ポリサルフアイ ド, ポリ塩化ビニルなどが, それぞれ, 燃焼性, 注型 性，機械的性質などに応じて用いられている32。

$7 \sim 8$ 年前までほぼ上記 2 方面に限られていた口ケ ットに打ける高分子物質の利用分野は, その後, 軽量 構造材料と耐熱材料の面で急速に注目を受けるように なつた。ロケットの推進能力は, 推進剤の性能のほ か, 推進剤に対する構造材や器材その他の重量比を小 さくすることで著しく増加する。したがつてこれらの 部分の軽量化は, 口ケット設計上の絶対的要謂であ
る。構造材として考えられる金属, 無機材料にくら べ, 有機高分子材料の比重はかなり小さく, ほとんど が 1 2 の範囲にある。高分子物質がロケット用材料 として浮び上つてくる理由はここにある。ただプラス チックスのみでは高強度の要求に応じることができな かつた。しかし, ガラス, 石英, アスベストなどの無 機繊維をポリエステル，エポキシ樹脂などに加えたい わゆる強化プラスチック（F.R.P. または単にR.P.) の技術が進み，その強度/重量比が他の構造材に匹適 し，または凌駕することが明らかになるにつれて， F.R.P. の利用が急速に進展した。とくに大きな口ケ ットモーターケースなどを, 強化纎維をマンドレルに まきつけて熱硬化性樹脂で固めて製造する filament winding の方法が確立されて以来, そののびは著し い7。1962 年のアメリカに扔けるロケットモーターケ 一スのうち, F.R.P.製のものは，ほぼ $2 \%$ に過ぎな いが，1965年には80\%を越し，1970年頃には，全構造 材の約半分が F.R.P.でつくられるものと，予想され ている1)。なお， 1962 年に扔ける航空およびミサイル 工業に利用された F.R.P. は約 3,000 万ポンド（F. R.P. 総生産量の約 $12 \%$ ) で8), そのうち $1 / 3$ 程度が ミサイル用と考えられる

ロケットに抢ける高分子材料のもら一つの進出分野 が，これから紹介する耐熱材料としてである。それで まずロケットがどのような熱的環況におかれるかを少 し検討してみよう。

\section{II ・ ロケットの耐熱要求}

ロケットのように非常に高速度で空気圈を通過する 物体が，空気の抵抗による著しい加熱を受けることは 流星の例からも容易に推測できる。この時発生する熱 は膨大なもので, その運動エネルギーがすべて熱エネ ルギーに変換して物体に加えられれば, 飛行体が完全 に蒸発してしまうほどである。幸いなことに, 高速飛 行体の前面は, 空気の断熱圧縮に伴ら衝撃波に覆わ れ, 大部分のエネルギーは, 衝撃波とともに飛行体の 側方から後方へと運び去られる。この割合は, 飛行体 
の形態, 速度, 高度 (空気密度) などに依存するが，実 際に飛行体に流入する熱量は, 全体の 1 10\% 程度上

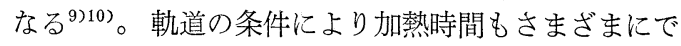
あるが，典型的な例を第 1 表に示した ${ }^{14)}$ 。ICBM のご とく短時間に急角度で落下するものは，低高度まで飛 行速度が大きいので, 衝撃波によつて消散する熱の割 合が大きく全熱流は比較的小さいが，単位時間あたり の熱流は非常に大きく, 瞬間的には $5,000 \mathrm{Btu} / \mathrm{ft}^{2} \cdot \mathrm{sec}$ に達する場合さえある ${ }^{12)}$ 。それに対し，人間衛星は揚 抵比を上げて滑空時間を長くするので衝撃波は弱めら れ, 飛行体に流入する全熱量は多いが, 熱流速は小さ い。勿論熱流速は, いっも一様ではなく, 再突入後空 気密度の増加とともに急速に増加し, ついで減速のた め再び減少する。衝撃波の内側で, 空気が飛行体に対 し静止したよどみ点における温度も, 条件によつて変 化するが，高度 10 万 $\mathrm{ft}$ (外圧 0.01 気圧, $-108^{\circ} \mathrm{F}$ ) に おける計算例では，第 2 表のごとく $6,000^{\circ} \mathrm{F} \sim 15,000$

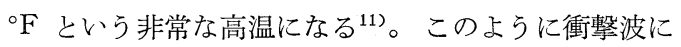
より大部分の熱が消散した後でも, な打空気圈通過の 際に飛行体の受ける空気力学的加熱は大変なもので, 何らかの方法で強力な熱保護を行なう必要に迫られ る。

\section{第 1 表 典型的な再突入時の環況 ${ }^{14)}$}

$\begin{array}{crrr}\text { 軌 道 } & \begin{array}{c}\text { 加熱時間 } \\ (\mathrm{sec})\end{array} & \begin{array}{c}\text { 最高熱流速 } \\ \left(\mathrm{Btu} / \mathrm{ft}^{2} \cdot \mathrm{sec}\right)\end{array} & \begin{array}{r}\text { 全 } \\ \left(\mathrm{Btu} / \mathrm{ft}^{2}\right)\end{array} \\ \text { I R BM } & 25 & 500 & 8,000 \\ \text { I C BM } & 35 & 2,000 & 35,000 \\ \text { 弾道衛星 } & 300 & 70 & 10,000 \\ \text { 滑空軌道 } & 6,000 & 80 & 150,000\end{array}$

\section{第 2 表 高度10万ft におけるよどみ点温度 ${ }^{11)}$}

$\begin{array}{cccc}\text { 軌 道 } & \begin{array}{c}\text { 速 度 } \\ (\mathrm{ft} / \mathrm{sec})\end{array} & \begin{array}{c}\text { よどみ点 } \\ \text { 温 } \\ \left({ }^{\circ} \mathrm{F}\right)\end{array} & \begin{array}{c}\text { よどみ点 } \\ \text { 压 } \\ (\mathrm{atm})\end{array} \\ \text { I R B M } & 11,500 & 6,090 & 1.87 \\ \text { I C B M } & 22,000 & 12,840 & 7.25 \\ \text { 衛星軌道 } & 25,000 & 15,440 & 9.45\end{array}$

ロケットにおいてもら一つ, 耐熱性の要求が必須の 部分がある。ロケット燃焼室およびノズルに関連した 場所がそれで，ここでも噴出する数千度の高温高圧ガ スに耐える材料が要求される。固体然料の場合予想さ れる条件は, 温度が $3^{`} 000^{\circ} \mathrm{F} \sim 9,000^{\circ} \mathrm{F}$, 内圧が 200 $\sim 3,000$ PSIA, 燃焼時間は数秒から数分にわたる ${ }^{13) 。 ~}$ 典型的な例を第 1 図に示した ${ }^{14)}$ 。ノズルの場合には， さらに噴出ガスの種類によつては化学反応の可能性も 考えなければならない。

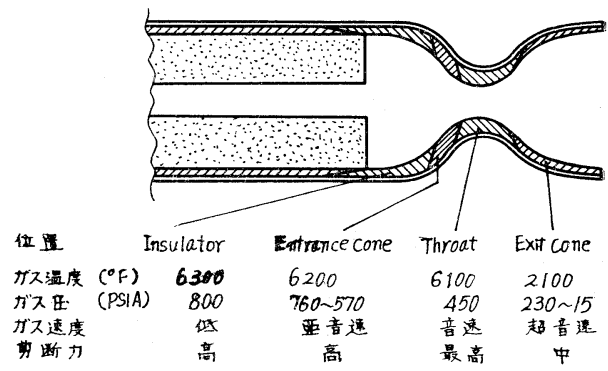

第 1 図 固体推進剂モーター ${ }^{14)}$

これらの苛酷な熱的条件に対処するため, これまで にいくつかの方法が試みられている。

輻射冷却法 (Radiation Cooling) は, 輻射率の高い 表面被覆を用い，高温で熱を輻射放散するもので，場 合によつては, 熱伝遒のよい材料で熱を飛行体側面に 運び低温部で輻射放冷することもある。Moのような 耐熱金属が用いられるが ${ }^{15)}$, 熱の吸収と輻射とが平衡 近くになるので, 短時間再突入のように極端に高温に なる場合には適さない。

熱貯槽法 (Heat Sink) は，比熱の大きい融点の高い 固体，たとえば Be などを用いて，熱容量により熱を 吸収する方法で, 全熱流の小さい場合には有効であ る。初期の弾道ミサイルには銅なども用いられたが 15), 軌道が大きく全熱流量が増加すると必要重量が著 しく大きくなるので望ましくない。

蒸発冷却法 (Transpiration Cooling) は, ロケット の尖端部の小孔板から水その他の揮発性または分解性 の物質を噴出させ, 蒸発または分解の吸熱作用を利用 するとともに, 生じた低温気体で境界層の冷却と熱流 阻止を行なわせるものである。特別な装置を必要とす る難点がありあまり利用されていないが26), 高速, 長 時間の加熱には有効である。

アブレーション冷却法 (Ablation Cooling) は, 熱 伝導性の悪い固体の被覆を利用するもので, 固体は, 昇華, 融解, 蒸発, 分解などで表面から徐々に失われ て (Ablate) ゆく。熱流はこれらの吸熱変化と比熱に よる熱吸収, および発生する多量の気体の泠却効果で 除かれる。熱伝導率が小さいので上述の変化はごく表 面層に限られ, 内部は低温に保たれる。熱流速が大き ければ，後述するように熱吸収能が増加するという一 種の自己制御的性質があるので，この方法はとくに高 熱流速の場合に適当である。一部 ICBM にはセラミ ックスが用いられているが(4)，七ラミックスは熱ひず みに弱く, また後でのべる理由から, アブレーション こそ高分子材料，あるいはこれに強化材を加えた F。 


\section{第 3 表高分子物質の熱的性質 ${ }^{17)(8)}$}

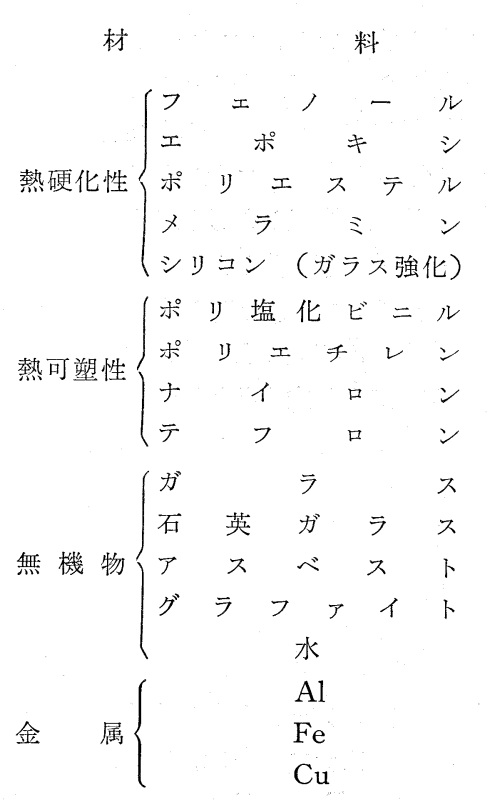

耐熱使用限度

$$
\sim 70
$$$$
\sim 150
$$$$
\sim 120
$$$$
\sim 100
$$$$
\sim 250
$$$$
\sim 70
$$$$
\sim 100
$$$$
\sim 150
$$$$
\sim 260
$$

(以下融点)

1, 700 1, 800

$$
\begin{array}{r}
- \\
3,500 \\
- \\
660 \\
1,530 \\
1,080
\end{array}
$$

$$
\begin{aligned}
& \text { 熱伝 導 率 } \\
& 3 \sim 6 \times 10^{-4} \\
& 4 \text { " } \\
& 4 \text { "I } \\
& \text { - } \\
& \sim 4 \\
& 3 \sim 7 \quad \text { " } \\
& 8 \text { " } \\
& 5 \sim 6 \text { " } \\
& 6 \text { " }
\end{aligned}
$$

$1 \sim 3 \times 10^{-3}$

$3.4 \prime$

$0.4 \sim 0.6 \quad$ "

37.7

1.4 "

$4.9 \times 10^{-1}$

1.5 "

$9.2 \prime \prime$
比 $\mathrm{cal} /{ }^{\circ} \mathrm{C} \cdot \mathrm{g}$ 熱比

$\sim 0.4$

1.3

1. $1 \sim 1.2$

$-$

$1.1 \sim 1.5$

$-$

1.5

$1 \sim 3$

$1.7 \sim 2.0$

$0.20 \sim 0.28$

$1.3 \sim 1.5$

0.55

0.9

1.1

0.40

2.2

2. $2 \sim 6$

2.2

3.0

2.3

1.0

2.7

7.8

8.9

R.P. の独断場である。

上記各泠却法は，それぞれ飛行条件に応じた特性を もつているが，有機高分子材料によるアブレーション 法は比較的安価で信頼性があり，重量の点からも有利 なため今後広く利用される勢いにある。たとえば， あ る IRBM の内部温度を $500^{\circ} \mathrm{K}$ 以下に保つために必 要な熱被覆重量の相対值は, シリカ䋊維強化フェノー ル樹脂 1 に対し，ガラス強化メラミン樹脂 2 , 未燒成 セラミック 2.5, Be 5.5, Cu 50 である ${ }^{16) 。 ~}$

\section{III. 高分子物質の熱的性質}

アブレーションの性格からわかるように，高分子材 料のロケットにおける耐熱性とは，それ自身が変化を 受けずに安定な材料として使用されるという意味では ない。この意味での高分子材料の耐熱使用限界は, 機 械強度の減少, 電気性質の劣化, 着色その他使用目的 に応じて判定基準がことなるが, 大略 $200^{\circ} \mathrm{C}$ 程度まで である。テフロン, シリコンなどがわずかにこれを超

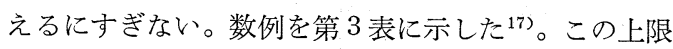
を拡げて普通の意味で耐熱性高分子を合成することは 高分子化学の大きな目標の一つであり, 共䡉環の導入 による安定性の向上とか, ヘテロ結合による結合エネ ルギーの増加とか多くの努力が行なわれ， $500^{\circ} \mathrm{C}$ 程度 まで安定な物質がいくつか出現しはじめた ${ }^{19) 20) 。 こ れ ~}$ らの材料も, 航空機やロケットの副次的耐熱材料とし て意味があるがここではこれ以上触れない。

高分子物質をその使用限界以上に加熱寸ると所謂熱

分解が起りはじめる。大部分の熱可塑性プラスチック スは, 解重合によりモノマーを放出するか，分子がで たらめに切断して低分子量気体となるかして重量が減 少し， $506^{\mathrm{C}} \mathrm{C}$ 以下でほとんど完全に消失してしまう ${ }^{21)}$ 。熱硬化性樹脂でも $200^{\circ} \sim 300^{\circ} \mathrm{C}$ から気体放出によ る重量損失が始るが， $1,000^{\circ} \mathrm{C}$ を越えても全部は消失 せず，炭素一炭素間結合の架橋，共䡉化を経てかなり の部分が炭化する。発生する気体は, テフロン，ポリ スチレンなどの解重合型では主としてモノマーであ り, ポリエチレンや熱硬化性樹脂では, 水素, 低級炭 化水素, また含む元素により, アンモニア, アミン, 水，炭酸ガスなどである熱可塑性樹脂の熱分解につい ては, 比較的研究が多く, 分解温度, 反応型式, 発生 ガス, 分解熱など相当知られているが22223), 熱硬化性 樹脂については，まだごく定性的なことしかわかつて おらず ${ }^{2425)}$, アブレーションの基礎的データとして研 究の促進が要求されている。

この他, 高分子材料の熱的特性は, わかりきつたこ とながら熱伝導性の著しく小さいこと，比熱が比較的 大きいことで,これれらも一括して, 他の材料と比較し て第 3 表に示した。

\section{IV. アブレーション}

アブレーション冷却法は, 1953年頃, ロケットノズ ルの研究にたまたま用いた強化プラスチックが, 表面 のみしか損傷しないことが明らかになつてから急速に 研究され，1958年には実際ロケットの尖端部の回収に 
応用され成功したといわれている ${ }^{16)}$ 。

高分子材料を, ロケットにみられるような高温, 急 速の熱流にさらすと, その低熱伝導性のため表面のみ が高温になり，前節でのべた分解反応は，ごくうすい 表面層でのみ起る。この層の厚みは, 材料や加熱条件 にもよるが, 普通数 $\mathrm{mm}$ 以下に過ぎない。グラフアイ トのよらに昇華性か, テフロンやポリエチレンのよら に融点と分解点の温度差の大きくないものでは, 吸熱 反応で生成した気体は表面から直接境界層に入るので これらは昇華材 (Sublimer) と呼ばれ, 熱硬化性樹脂 では分解残渣が炭化層として残るので炭化材と呼ばれ ている。炭化材では, 内側の分解層;で発生する気体 は，炭化層の小孔をとおりながらこれを冷却して表面 に出てゆき, 炭化層はグラファイト同様, 昇華と空気 中の酸素による酸化で失われるが, それ以外に, 適当 な厚さになると気流の圧力やずりの力に耐えられずに はがれてゆく。強化繊維がある場合には, 繊維がこの 炭化層を内部の未反応層につなぎとめて補強する。シ リカやガラスの無機繊維は融解して液層となり表面を 覆うか, 小さな液滴となつて炭化層にまじる。液層は 気流のため，粘度に応じて側方一流されるが，一部は 熱を吸収しながら蒸発する。いずれの場合にも発生し たガスは表面を覆い，境界境を厚くして熱流を妨げ る。この気体による冷却効果は, アブレーションにお ける重要な因子の一つである。炭化層を形成する場合 には表面に脑ける輻射冷却の効果も大きい。第 2 図 に，炭化層をつくる場合を模型的に示した。

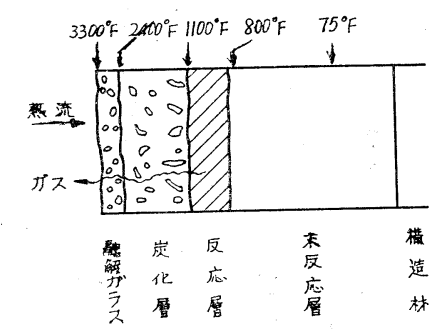

\section{第 2 図 ガラス強化フェノール樹脂} のアブレーション模型図 ${ }^{26)}$

各種材料のアブレーション泠却の效率は, アグレー ション熱またはアブレーション速度で比較できる。ア ブレーション速度は単位時間, 単位表面積あたり失わ れる物質の量, アブレーション熱は, 熱流速度をアブ レーション速度で除したもので, 損失単位重量あたり の吸熱量を示す。この場合, 表面の輻射冷却を吸熱効 果の一部と考えるが27)，流大する熱がそれだけ小さく なつたと考えるかで ${ }^{29)} 2$ とおりのアブレーション熱が
定義されているが，ここでは後者を用いる。もちろん アブレーション熱が大きいか，アブレーション速度が 小さいものがすぐれた泠却效果をもつが同一定常流速 では両者は逆数関係にあるから, どちらで比較しても よい。アブレーションが定常的でない場合や, 熱流速 のことなる場合の比較は注意しなければならない。

上記 2 量が，一定熱流速で失われる被覆の厚さを決 定するのに対し，主として熱伝導率に支配される表面 および内部温度分布が, 初期の目的に応じた内部の保 護温度を保つのに必要な未変化被覆の厚さを決定す る。たとえば，グラファイトのアブレーション速度は 非常におそいが，表面温度が高く，しかも熱伝導がプ ラスチックにくらべはるかに大きいので，かなり内部 まで高温になる。

\section{$\mathrm{V}$. 。高分子材料の冷却効率}

アブレーション熱は, 昇華材のように比較的単純な 挙動を示すもので, 熱的データがある場合にはこれか ら概算できる。たとえばテフロンは, $620^{\circ} \mathrm{F}$ における 融解熱 $37 \mathrm{Btu} / l b, 750^{\circ} \mathrm{F}$ から始る解重合熱は外部の 条件で多少ことなるがほぼ 660 ６90 Btu/lb，比熱は 融解前後であまり大差なくほぼ $0.27 \mathrm{Btu} / l b^{\circ} \mathrm{F}$ である から, 窒温から $800^{\circ} \mathrm{F}$ までの吸熱量は大略 $200 \mathrm{Btu} / l b$, したがつて分解までの全吸熱量は約 $900 \mathrm{Btu} / l b$ であ る。解重合で生じた気体モノマーはさらに冷却作用を もつ。この効果は境界層両側のエンタルピー差が大き いほど著しく, 第 3 図 ${ }^{29)}$ からかるように高エンタル ピー差の場合にはアブレーション熱の相当な部分を占 めている。一般に気体泠却効果は, 上述のエンタルピ 一差のほか, 生成気体の分子量が小さいものほど大き く，また気流が層流の場合には, 乱流の場合にくらべ 数倍大きい。熱流速が大きいほど冷却効果が高くなる といらアブレーションの利点は，もつぱらこの気体冷 却効果によるものである。温度が著しく高くなると， さらに気体の吸熱解離も起り得る。たとえば水素分子

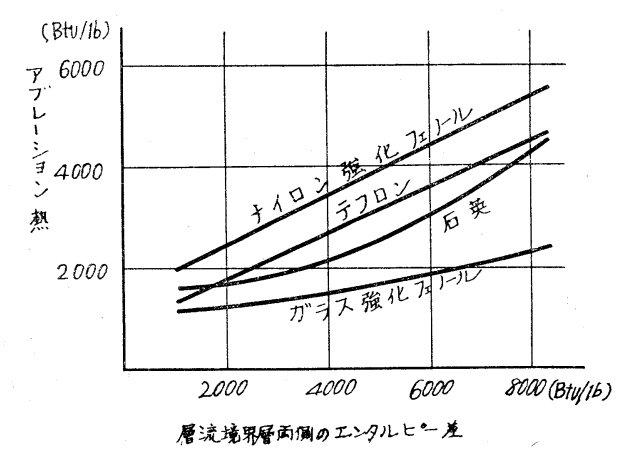

第 3 図 アブレーション熱299 
は, $6,200^{\circ} \mathrm{F}$ 以上では 10 万 $\mathrm{Btu} / l b$ もの吸熱反応で 原子に解離する。これらのことから, 低温で低分子量 気体を多量に発生する高分子物質が，アブレーション 材料として適していることが理解できる。

熱硬化性樹脂や強化材を含むものについては, 分解 の基礎的データ不足の他, 炭化層のはがれとか, 無機 繊維の融解流動による損失とかの複雑な現象を伴うた め, アブレーション熱の概算は難しく, アブレーショ ン速度の実験から直接求めることになる。たとえば石 英の蒸発潜熱は $5,500 \mathrm{Btu} / l b$ といら大きさであるが, 実際に観測されるアブレーション熱は, 融解後流動で 失われて蒸発に等与しない量が多いためずつと低くな
る。炭化材とか融解流動するものについては, 全量の らちどれだけが気体になるかといら気体転化率がアブ レーション熱に大きく影響する。

多くの物質についてアブレーション熱または速度が 調べられているが1112)16)29)30), 実験条件がまちまちで あり, 熱流速とか, 後述するように強化材の配向とか 成型法なども影響するため, 簡単に比較しにくい意味 がある。しかしごく概括的にいつて，樹脂としてはフ ェノール樹脂がもつともよい性質を示し，ついでやは り芳香族系のフラン樹脂, それからメラミン, シリコ ン，エポキシ，ポリエステルなどが類似の性質を示す ようである。一例を第 4 表に示した。

\section{第 4 表 アブレーション 熱 ${ }^{299}$}

（熱流速 $750 \mathrm{Btu} / \mathrm{ft}^{2} \cdot \mathrm{sec}$, 露出時間 $10 \mathrm{sec}$ )

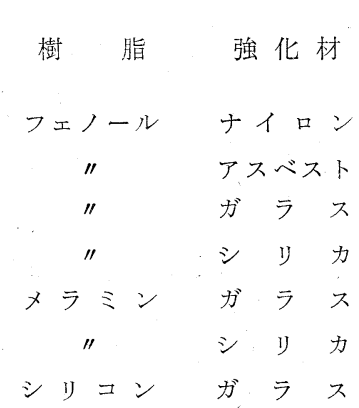

\begin{tabular}{|c|c|c|c|}
\hline \multirow[t]{7}{*}{ 強化材\% } & $40 \%$ & $55 \%$ & $70 \%$ \\
\hline & 7,200 & 7,600 & 6,400 \\
\hline & 5,600 & 5,500 & - \\
\hline & 6,000 & 5,800 & 4,900 \\
\hline & 7,000 & 7,800 & 7,900 \\
\hline & 3,800 & 3,900 & 4,600 \\
\hline & - & 6,900 & 7,900 \\
\hline & - & - & 6,000 \\
\hline
\end{tabular}

\begin{tabular}{rrr} 
減 & 重 \\
\hline $40 \%$ & $55 \%$ & $70 \%$ \\
5.66 & 5.38 & 6.37 \\
7.27 & 7.45 & - \\
6.90 & 7.01 & 8.37 \\
5.84 & 5.29 & 5.18 \\
10.89 & 10.54 & 8.84 \\
- & 5.91 & 5.18 \\
- & - & 6.97
\end{tabular}

強化材には，ナイロン，オーロンなどの有機繊維 と, ガラス, 石英, アスベスト, グラファイトなどの 無機繊維が用いられるが，無機繊維では，ごく一般的 にいつて, シリカ, 石英などのように, 融解状態で粘 度の高いものがよい。しかしアスベストは熱伝導率の 低い点で温度分布に対し有利である。有機補強材は, $2 \sim 3,000^{\circ} \mathrm{F}$ の低温では無機繊維に劣るが，5〜6,000 ${ }^{\circ} \mathrm{F}$ 以上の高温になると, 第 5 表のように, 無機繊維 よりずつと有効になる ${ }^{11)}$ 。これは睡述の気体による冷 却効果が大きくなることや無機補強材の流動損失など が原因と考えられる。樹脂と補強材の比率による影響 は, 第 4 表のごとく材料の組合せによりまちまちであ る。

\section{第 5 表 アブレーション熱11)}

\begin{tabular}{|c|c|c|c|}
\hline \multirow{2}{*}{ 都 } & \multirow{2}{*}{$\begin{array}{c}\text { 強化 材 } \\
(\%)\end{array}$} & \multicolumn{2}{|c|}{ アブレーション熱(Btu/lb) } \\
\hline & & 露出温度 $6,400^{\circ} \mathrm{F}$ & $23,000^{\circ} \mathrm{F}$ \\
\hline エノール & $\begin{array}{l}\text { ナイロン } \\
(52 \%)\end{array}$ & 11,500 & 14,700 \\
\hline " & $\begin{array}{c}\text { ガ ラ } \\
(43 \%)\end{array}$ & 6,800 & 9,200 \\
\hline " & $\begin{array}{c}\text { シ } \\
(39 \%)\end{array}$ & 9,000 & 10,450 \\
\hline
\end{tabular}

無機繊維の配向もアブレーション性能に大きな影響 をもつ。露出温度 $5,000^{\circ} \mathrm{F}$ の実験で, 同一組成のシリ カ繊維強化フェノール樹脂をくらべると, 繊維が表面 に対して平行な場合のアブレーション速度にくらべ, 垂直と $45^{\circ}$ 方向の場合は, それぞれ約 $1 / 2$, および $1 / 3.5$ と著しく改良される ${ }^{30)}$ 。平行な場合には, 繊維 層の間で樹脂が分解して繊維がはがれやすいためと考 えられる。垂直のものは, 機械的強度が小さく, また 熱伝導率も上るので, 適当な角度をもたせたものがア ブレーションに向いている。これと関連して成型法も 非常に重要であり，たとえばアスベスト強化フェノー ル樹脂を（樹脂 $57 \%$ ) 種々の方法で成型して一定厚み の噴出管とし，これにロケット推進時の条件の高温気 体をとおした時の耐炎時間を比較すると, スピン成型 がもつとも優れて $170 \mathrm{sec}$, 押出成型 $30 \mathrm{sec}$, 圧縮成型 $20 \mathrm{sec}$, 注型法のものは全然䭾目であつた ${ }^{30)}$ こここと は, 樹脂と強化材の量的関係よりも, その内部構造, つまり強化材繊維の太さ, 配向や分布, 樹脂の硬化 度, 樹脂と繊維の密着度などが, 機械的強度, 熱伝導 率, 気体転化率, 炭化層, 融解層の状態などを介して アブレーションに大きく影響していることを示すもの 
と考えられる。これらの問題についての研究はまだ比 較的少く, 今後の課題として残されている。

このほかアブレーション泠却に寄与するものとして 表面からの輻射冷却がある。ステファン・ボルツマン の法則からわかるように，この効果は表面温度が高く なると急激に大きくなる。とくに炭化材では黒体輻射 に近い大きな輻射能をもつ利点がある。無機強化材が あると融解層が表面を覆うので輻射能は下る。第 6 表 に各種材料の表面温度と輻射冷却の効率を示した。し かし輻射能の高いことは同時に吸収能の高いことを意 味し，飛行体の尖端のよどみ点や，燃焼室内の高温ガ スからの表面への輻射を吸収する。よどみ点の輻射加 熱の強さは, 対流加熱が $100 \mathrm{Btu} / \mathrm{ft}^{2} \cdot \mathrm{sec}$ 程度の時には $1 \%$ 足らずであるが， $1,000 \mathrm{Btu} / \mathrm{ft}^{2} \cdot \sec$ では $10 \%$ 前 後になり，数千 $\mathrm{Btu} / \mathrm{ft}^{2} \cdot \sec$ でに両者が同程度の大き さになる ${ }^{10)}$ 。したがつて輻射冷却の効果は, 外部条件 に大きく依存する。また融解層がある場合に注, 表面 から内部への輻射が，内部の温度分布を変え，粘度， 気体転換率を介してアブレーション熱に変化を与える など, 輻射の有無はアブレーション過程全体に大きな 影響を与える ${ }^{26)}$ 。

\section{第 6 表 輻射冷却効率 ${ }^{26)}$}

薣脂強化材表面温度輻射率輻埶射 $\left({ }^{\circ} \mathrm{F}\right) \quad(\%) \quad \mathrm{Btu} / \mathrm{ft}^{2} \cdot \mathrm{sec}$

$$
\begin{array}{rrrrrr}
\text { テフロン } & - & & \sim 1,300 & \sim 0.8 & 4 \\
\text { フェノール } & \text { アスベスト } & \sim 3,200 & \sim 0.6 & 52 \\
\text { " } & \text { ガ } & \text { ス } & \sim 3,300 & \sim 0.5 & 48 \\
\text { " } & \text { 石 } & \text { 英 } & \sim 4,300 & \sim 0.5 & 123 \\
\text { " } & \text { ナイロン } & \sim 4,500 & \sim 0.8 & 233
\end{array}
$$

\section{VI. 高分子祆料の断熱効果}

アブレーション面から内側の耐熱材の内部温度分布 は，実際江熱保護を与える物体の温度を一定以下に保 つためのデータとして重要である。第 3 表のごとく高 分子物質の熱伝率, 比熱, 比重は大同小異で, した がつて熱拡散率もほぼ同じであるが，その值はガラ ス，石英などより 1 桁，グラファイトより 2 析低い。 これが重要な点であるが，そのほかにもいくつかの因 子が問題となる。まず表面の温度であるが，これは主 として材料の熱分解反応の速度論的因子と熱拡散率の ような材料固有の熱的性質に依存し，熱流速のような 外的条件の影響は少い。第 4 図にテフロンのアブレ一 ション速度と表面温度の関係を示した ${ }^{211}$ 。アブレーシ ョン速度の対数目盛から考えて, この速度を介して表 現されている熱流速のような外的条件の変化の影響の
小さいことがわかる。それにすでにのべたように，熱 流速が大きくなるとアブレーション熱が大きくなるた め，アブレーション速度はそれほど大きくならない。 したがつて表面温度は通常ほぼ一定とみてよく, テフ ロンで $\sim 1,200^{\circ} \mathrm{F} ，$ ガラスフェノール系で $3,300^{\circ} \mathrm{F}$, ナイロン・フェノール系で $4,500^{\circ} \mathrm{F}$ 程度である。

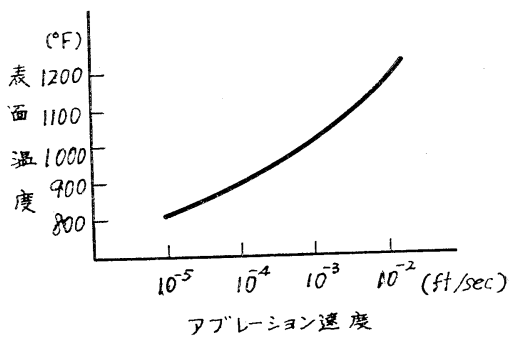

\section{第 4 図 テフロンの表面温度と アブレーション速度}

内部の温度分布は通常の熱拡散と同様に考えてよい が，アブレーションに特有な点は, アブレーション速 度が温度分布に影響することで, 同一材料ではこの速 度の大きいものほど，みかけの熱拡散率が小さくなる 27)。このた为熱流速が非常に大きくてアブレション速 度が増加すると，表面温度も上るが，内部の温度勾配 が鋭くなつて，保護層の厚みは却つて少くてよいこと になる。第 5 図は, 一例として, 適当な熱的パラメー 夕をもつ仮想的炭化材について, 炭化層の下, 分解層 の表面の温度の上昇により, 内部温度分布がどれだけ 鋭くなるかを示している ${ }^{28)}$ 。

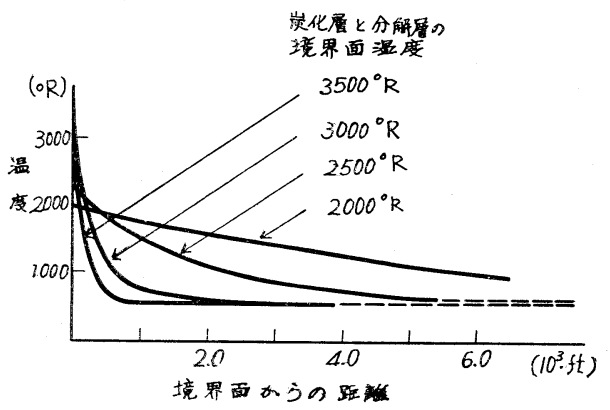

第 5 図 炭化材の内部温度

以上のべてきたように，アブレーションにより失わ れる厚みと, 内部保護に必要な厚みは外的条件と材料, の性質によりさまざまである。第 6 図は, テフロンと グラファイトについて, 突入時間約 $300 \mathrm{sec}$ の比較的 おそい軌道についてのアブレーションによる表面後退 と, 内部温度分布を示す。三本の線はそれぞれ 152, 232，262 sec 後の場合に対応する。熱流速が小さい 


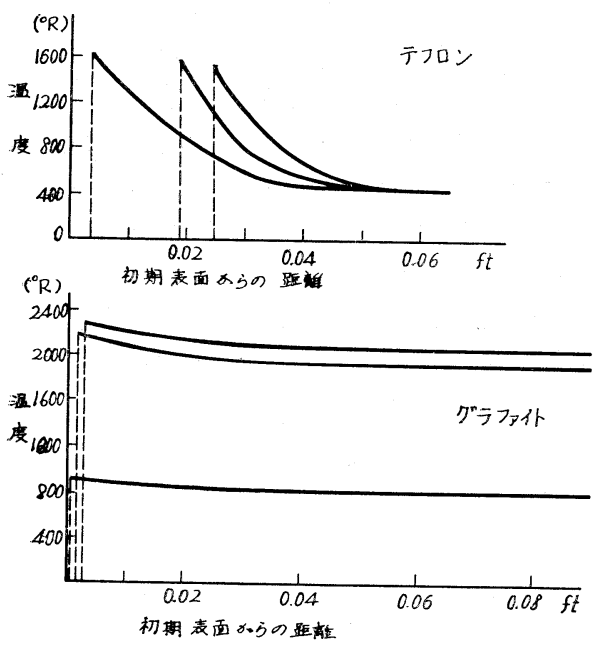

第 6 図 アブレーション速度と内部温度

第 7 表 内部を室温に保つために必要な厚み

\begin{tabular}{|c|c|c|c|c|c|}
\hline \multirow[b]{2}{*}{ 材 } & \multirow[b]{2}{*}{ 料 } & \multicolumn{2}{|c|}{$\begin{array}{l}\text { 突 大時間 } \\
\text { 約 } 300 \mathrm{sec}\end{array}$} & \multicolumn{2}{|c|}{$\begin{array}{l}\text { 突 入時間 } \\
\text { 約 } 40 \mathrm{sec}\end{array}$} \\
\hline & & $\begin{array}{c}\text { 表 面 } \\
\text { 損失量 } \\
\text { (ft) }\end{array}$ & $\begin{array}{c}\text { 最 低 } \\
\text { 保温量 } \\
\text { (ft) }\end{array}$ & $\begin{array}{c}\text { 表 面 } \\
\text { 撌失量 } \\
\text { (ft) }\end{array}$ & $\begin{array}{c}\text { 最 低 } \\
\text { 保温.量 } \\
\text { (ft) }\end{array}$ \\
\hline ᄀ & ロン & 0.026 & $\sim 0.01$ & 0.1 & 0.001 \\
\hline 石 & 英 & 0.01 & $\sim 0.8$ & 0.07 & $\sim 0.03$ \\
\hline バニー & イイト & 0.001 & - & 0.01 & \\
\hline
\end{tabular}

テフロン, 石英の密度はどちらも約 $140 \mathrm{lb} / \mathrm{ft}^{3}$

ためグラファイトのアブレーションは平衝に達せず表 面温度はかなり低いが，それでも表面後退にくらべ温 度侵入の著しいことがよくわかる。テフロンでは逆に 最終的に失われる厚みの方が, 保温層よりも大きい。 石英の場合には，第 7 表のごとく，高熱導率のため, グラファイトほどではないがテフロンの 10 倍近い保 温層を必要とする。しかし, 落下時間が $40 \sim 50 \mathrm{sec}$ 程 度の急速加熱の場合には, 必要な断熱厚みに著しく減 少する。

これまで, 接触気体とアブレーション材料との化学 反応には触れなかつたが，たとえばノーズコーンでは 空気による酸化の問題がある。炭化材の炭素々酸素に よる $\mathrm{CO}$ の生成は $3,960 \mathrm{Btu} / \mathrm{lb} \mathrm{C}$ もの発熱反応であ り,さらに炭酸ガスになる場合 $4,340 \mathrm{Btu} / l b \mathrm{CO}$ の発 熱がある。ただ全部の炭素が酸化を受けるのでないこ とと, 発生気体による冷却効果のため発熱が打消され るため，極端に大きな影響はないといわれている ${ }^{25) 。 ~}$ ノズル材料の場合にも噴出気体の種類が影響をおよぼ す。たとえば酸素-RP-1 系推進剤を使用するとナイ ロンーフェノール樹脂の炭化層の消耗が烈しいが，シ
リカーフェノールでは ガラス状の融解層の被覆のため 酸化が怙さえられる ${ }^{31)}$ 。また, $\mathrm{F}_{2} / \mathrm{H}_{2}$ 系推進剤で炭化 層の消耗が少ないのは, この表面温度では生成気体が 炭素と反応しないからと考えられる。

以上, 高分子材料のアブレーション特性の概要をの べたが，実際にどのような材料を用いればよいかは， 個々のロケットの要求に応じてことなり，“ただ 1 種 の優れた耐熱材料というものはない”2)。高熱流速で. 気体が層流をなすものでは，気体転化率の高い昇華材 がよいし, 乱流であれば, 蒸発熱の高い, 高粘度の無 機強化材を含むものがよい。長時間飛行には熱伝導率 の低いものが望ましく, 短時間高速では, アブレーシ ョン熱や輻射効率の高いものがよい。またノズルのよ うに寸法安定性の要求されるところでは, アブレーシ ョン速度が小さくて排気に安定なものでなければなら ない。

内部温度をどの程度に保つかも, 材料決定の重要な 因子である。たとえば人間の載つているカプセルの"筑 護と, 単に機械的強度を保てばよいノズルとでは全然 ことなる。後者の場合, 強度さえ保てるなら, むしろ 断熱的でなく, 飛行体外面まで高温のままとし, ここ から輻射冷却を行ならこともできる。

実際の再突入の飛行テストを行なつたプラスチック の例を, 全熱流量の小さな順にあげると, Scout にテ フロン, Mercury にフェノールーガラス, Discoverer にフェノールーナイロンなどがあり, Fire 1 にはフェ ノールアスベストが用いられると思われる ${ }^{15)}$ これれら はいずれも比較的短時間飛行のものであるので, 今後 数10分から数時間といら再笑入に対するアブレーショ ン材料の飛行テストが望まれている。

最後に, 既成のものでなく, 新しく開発中の高分子 材料でアブレーションに利用できそうなものの例を 一，二あげる。一つは，リンを含む高分子で，有機リ ン化合物の難燃性, 弹性残渣の生成, 金属によく付着 するなどの性質を役立てるため, リンを含むフェノー ル樹脂が合成され, 研究が進められている32)。もう一 つは, 水を多量に含むプラスチックで, 逆乳化重合法 により,プラスチック自身の10倍近くもの水を微小滴 として分散して重合, 硬化すると, 水の高、蒸発熱, 分子量の低、水蒸気の発生, 低、熱伝導率などから優 れた耐熱材ができる ${ }^{33}$ 。ただ機械的強度に問題がある と思われるが, 強化材を入れることも可能であり, 非 常に興味のある材料である。

\section{文献}

1) Mod. Plast., 39, 75 (Feb. 1962) 
2) Materials for Missiles and Spacecraft (Mc Graw-Hill, 1963)

a) J. C. Mc Donald; pp. 1

b) W. H. Steuex; pp. 94

3）山崎毅六；高分子，11，654 (1962)

4) J. A. Kies \& H. Bernstein; Mod. Plast., 40, 147 (Nov, 1962)

5) A. W. Wilson; Brit. Plast., 33, 352 (1960)

6）河田幸三；高分子，11，644，(1962)

7) Mod. Plast., 40, 95(Feb. 1963)

8) Mod. Plast., 40, 104 (Jan. 1963)

9) J.V. Becker; 自然, 16, 24, (1961，5月)

10) J. N. Kotanchik \& D. H. Greenshields; Aerospace Engg., 22, 192 (1963)

11) I. J. Gruntfest \& L.H. Shenker; Rocket and Missile Technology, Chem. Engg. Progress Symposium Series, 33, 77 (1961)

12) N. S. Diaconis, J. B. Fanucci \& G. W. Sutton; Advances in Ballistic Missile and Space Technology, 2, 463, (1961)

13) W. C. Hourt; Ind. Eng. Chem., 52, 761 (1960)

14) J. M. Kelbe \& J. E. Bernados; Aerospace Engg., 22, 56, (1963)

15) L. Roberts; Proceedings of NASA-University Conference on theScience and Technology of Space Exploration, NASA SP 11 2, 461 (1962)

16) W. R. Lucas \& J. E. Kingsbury; Mod.
Plast., 38, 135 (Oct. 1960)

17）プラスチックハンドブック（朝倉書店，1962）

18）理化学辞典（岩波書店）

19）高分子の合成（化学同人，1962）岩倉義男, 宇 野敬吉 pp. 269

20) C. S. Marvel; 講 演要旨集 (東京大学, 他, 1963，10月）

21）神戸博太郎；高分子 11，659 (1962)

22) H. H. G. Jellinek; Degradation of Vinyl Polymers (Academic Press, 1955)

23) L. A. Wall \& J. H. Flynn; Rubber Chem. Tech., 35, 1157 (1962)

24) H. C. Anderson; J. Appl. Polym. Sci., 6, 484 (1962) 他

25) K. D. Jeffreys; Brit. Plast., 188 (April 1963)

26) D. L.Schmidt; Mod. Plast., 38, 147 (1960)

27) P. G. Simpkins; J. Roy. Aeronaut. Soc., 66, 387 (1962)

28) S. M. Scala \& L. M. Gilbert, A. R. S. Journal; 32, 917 (1962)

29) D. L. Schmidt; Mod. Plast., 38, 131 (Nov. 1960)

30) J. H. Lux; Rocket and Missile Technolgy, Chem. Eng. Progreos Series, 33, 72 (1961)

31) E. P. Bartlett; Aerospace Engg., 22, 86 (1963)

32) I. E. C., 55, 7 (1963)

33) Brevet Belgique, $N^{\circ}$ 623,754 (1963.2.15)

\title{
Materials for Rockets and Spacecraft
}

\section{-(II) Plastics as Heat Resistant Materials-}

\author{
by Itaru Mita \\ (Institute of Space and Aeronautical Science, University of Tokyo)
}

SYNOPSIS : - The present article reviews briefly on the status in quo of the use of plastics as heat resistant materials. Attention is particularly focused on a cooling method called ablation. The characteristics of ablation are presented and the factors which affect them are analysed and compared. 